\title{
Self-organization to sub-criticality
}

\author{
$\checkmark$ Priesemann $n^{1,2}$ \\ From 24th Annual Computational Neuroscience Meeting: CNS*2015 \\ Prague, Czech Republic. 18-23 July 2015
}

Human brains possess sophisticated information processing capabilities, which rely on the interactions of billions of neurons. However, it is unclear how these capabilities arise from the collective spiking dynamics. A popular hypothesis is that neural networks assume a critical state $[1,2]$, because in models criticality maximizes information processing capabilities [3,4]. However, it has been largely overlooked that criticality in neural networks also comes with the risk of spontaneous runaway activity [5], which has been linked to epilepsy. Does the brain indeed assume a critical state, despite the risk of instability? To revisit this question, we analyzed spiking activity from awake animals, instead of more coarse measures of neural activity (population spikes, LPF, EEG, BOLD) as in most previous studies. In all recordings (rats hippocampus, cats visual cortex, and monkey prefrontal cortex), spiking activity resembled a sub-critical state, not criticality proper [6]. We confirmed these results using a novel mathematical approach that is robust to subsampling effects [7] [see Wilting \& Priesemann, conference proceedings CNS 2015]. While 'self-organization' to criticality has been widely studied (e.g.[5,8]), it is unclear what mechanism allows self-organize to sub-criticality instead. Here, we demonstrate that homeostatic plasticity [9] assures that networks assume a slightly sub-critical state, independently of the initial configuration. Surprisingly, increasing the external input (stimuli) altered the set-point of the network to a more sub-critical state. Our results suggest that homeostasis allows the brain to maintain a safety margin to criticality. Thereby the brain may lose processing capability, but avoids instability.

\section{Authors' details}

'Department of Nonlinear Dynamics, Max Planck Institute for Dynamics and Self-Organization, Göttingen, Germany. ${ }^{2}$ Bernstein Center for Computational Neuroscience, Göttingen, Germany.

\footnotetext{
Correspondence: viola@nld.ds.mpg.de

'Department of Nonlinear Dynamics, Max Planck Institute for Dynamics and Self-Organization, Göttingen, Germany

Full list of author information is available at the end of the article
}

Published: 18 December 2015

\section{References}

1. Beggs JM, Plenz D: Neuronal avalanches in neocortical circuits. J Neurosci 2003, 23:11167-11177.

2. Priesemann V, Valderrama M, Wibral M, Le Van Quyen M: Neuronal Avalanches Differ from Wakefulness to Deep Sleep-Evidence from Intracranial Depth Recordings in Humans. PLoS Comput Biol 2013, 9: e1002985

3. Boedecker J, Obst O, Lizier JT, Mayer NM, Asada M: Information processing in echo state networks at the edge of chaos. Theory Biosci 2012, 131:205-213.

4. Bertschinger $N$, Natschläger $T$ : Real-time computation at the edge of chaos in recurrent neural networks. Neural Comput 2004, 16:1413-1436.

5. Bak P, Tang C, Wiesenfeld K: Self-organized criticality: An explanation of 1/f noise. Phys Rev Lett 1987, 59:381-384.

6. Priesemann V, Wibral M, Valderrama M, Pröpper R, Le Van Quyen M, Geisel T, et al: Spike avalanches in vivo suggest a driven, slightly subcritical brain state. Front Syst Neurosci 2014, 8:108.

7. Priesemann $V$, Munk MH, Wibral M: Subsampling effects in neuronal avalanche distributions recorded in vivo. BMC Neurosci 2009, 10:40.

8. Levina A, Herrmann JM, Geisel T: Dynamical synapses causing selforganized criticality in neural networks. Nat Phys 2007, 3:857-860.

9. Turrigiano G: Homeostatic synaptic plasticity: local and global mechanisms for stabilizing neuronal function. Cold Spring Harb Perspect Biol 2012, 4:a005736.

doi:10.1186/1471-2202-16-S1-019

Cite this article as: Priesemann: Self-organization to sub-criticality. BMC Neuroscience 2015 16(Suppl 1):019.
Submit your next manuscript to BioMed Central and take full advantage of:

- Convenient online submission

- Thorough peer review

- No space constraints or color figure charges

- Immediate publication on acceptance

- Inclusion in PubMed, CAS, Scopus and Google Scholar

- Research which is freely available for redistribution

Submit your manuscript at www.biomedcentral.com/submit
() Biomed Central
() Biomed Central

(C) 2015 Priesemann This is an Open Access article distributed under the terms of the Creative Commons Attribution License (http:// creativecommons.org/licenses/by/4.0), which permits unrestricted use, distribution, and reproduction in any medium, provided the original work is properly cited. The Creative Commons Public Domain Dedication waiver (http://creativecommons.org/publicdomain/ zero/1.0/) applies to the data made available in this article, unless otherwise stated. 